Beata Bury (i) https://orcid.org/0000-0002-7437-1117

Sąd Rejonowy w Rzeszowie

\title{
KILKA REFLEKSJI NA TEMAT „ZADANIOWEGO” CZASU PRACY SĘDZIÓW
}

\author{
Abstract \\ Some reflection on the judges' "task-based" working time
}

In accordance with the Art. 83 of the Act of 27 July 2001, Law on the Organization of Common Law Courts, the judge's time of work is specified by its tasks. The employment relationship of judge has some specificity, as regards the scope of staff subordination due to the principle of judicial independence. Typical, traditional understanding of employment subordination is not applied here, as it would be in a collision with it. The judge is required to perform the commands of superiors only in respect of administrative acts and on the efficiency of court proceedings. In this connection, the question arises as to whether this circumstance is sufficient to defend the argument that the legal status of a judge is so different, that his working time should not be in the framework of working time standards and that this is not "task-based" working time in the meaning of the Art. 140 of the Labor Code.

Słowa kluczowe: czas pracy, zadaniowy czas pracy, norma czasu pracy, stosunek pracy sędziego

Keywords: working time, task-based working time, working time standard, employment relationship of judge

ASJC: 3308, JEL: K31

\section{Wprowadzenie}

Ustawa z dn. 27 lipca 2001 r. - Prawo o ustroju sądów powszechnych (Dz.U. 2019, poz. 52 tekst jedn. ze zm., dalej: „Prawo o ustroju sądów powszechnych”, „p.u.s.p.”) należy do pragmatyk pracowniczych, którymi są akty prawne regulujące status prawny różnych grup zawodowych w sposób odbiegający od przepisów ustawy z dn. 26 czerwca 1974 r. Kodeks pracy (Dz.U. 2019, poz. 1040 tekst jedn. ze zm., dalej: „Kodeks pracy”, „k.p.”), tj. powszechnego prawa pracy (Seler 1974, s. 4 i n.; Piotrowski 1987, s. 99 i n.; Liszcz 1989, s. 24). Artykuł 5 k.p. określa relację między przepisami pozakodeksowymi prawa pracy a przepisami zawartymi w Kodeksie pracy, stanowiąc, że jeżeli stosunek pracy 
określonej kategorii pracowników regulują przepisy szczególne, przepisy Kodeksu pracy stosuje się w zakresie nieuregulowanym tymi przepisami. Zależność tę można określić formułą: lex specialis derogat legi generali, co przesądza o posiłkowej roli przepisów kodeksowych w zakresie regulowanym przez pragmatykę.

Przedmiotem specyficznej regulacji w poszczególnych pragmatykach pracowniczych są najczęściej: sposób nawiązania i rozwiązania stosunku pracy, warunki pracy i wynagrodzenie, odpowiedzialność pracownicza, a także czas pracy i urlopy. Pragmatyki - w sposób mniej lub bardziej szczegółowy - regulują czas pracy grup zawodowych objętych przedmiotowym zakresem ich działania. Rozwiązania w nich przyjęte są niekiedy bardzo rozbudowane (np. ustawa z dn. 16. kwietnia 2004 r. o czasie pracy kierowców, Dz.U. 2012, poz. 1155 tekst jedn. ze zm.), ale zdarzają się również unormowania bardzo lakoniczne (np. wspomniane Prawo o ustroju sądów powszechnych - analogiczne rozwiązanie przewiduje art. 29 ustawy z dn. 25 lipca 2002 r. - Prawo o ustroju sądów administracyjnych, Dz.U. 2018, poz. 2107 tekst jedn. ze zm.; art. 43 ustawy z dn. 8 grudnia 2017 r. o Sądzie Najwyższym, Dz.U. 2019, poz. 825 i art. 99 ustawy z dn. 28 stycznia 2016 r. - Prawo o prokuraturze, Dz.U. 2019, poz. 740.

Stosunek pracy sędziego cechuje pewna specyfika, jeżeli chodzi o zakres podporządkowania pracowniczego z uwagi na zasadę niezawisłości sędziowskiej. Nie znajduje tutaj zastosowania typowe, tradycyjne rozumienie podległości służbowej, gdyż pozostawałoby z nim w kolizji. Sędzia ma obowiązek wykonywania poleceń przełożonych jedynie w zakresie czynności administracyjnych oraz dotyczących sprawności postępowania sądowego. W związku z tym powstaje pytanie, czy okoliczność ta jest wystarczająca do obrony argumentu, że status prawny sędziego jest na tyle odmienny, że jego czas pracy nie powinien mieścić się w normach czasu pracy.

\section{Istota zadaniowego czasu pracy}

W pierwszej kolejności autorka zwraca uwagę na tytuł niniejszego opracowania. Otóż ujęcie formuły „zadaniowy czas pracy” w cudzysłów stanowi odzwierciedlenie istniejących w tym przedmiocie wątpliwości. Kontrowersje, czy sędziowie pracują w zadaniowym, czy też w innym systemie czasu pracy, są bowiem nadal aktualne. Przyjmując, że sędziowie wykonują pracę w tym systemie czasu pracy, art. 83 pragmatyki należy uznać za lex specialis w stosunku do art. 140 k.p. (co wynika z odesłania zawartego w art. 5 k.p.).

Zgodnie z art. 83 p.u.s.p., zwanej dalej „pragmatyką", czas pracy sędziego jest określony wymiarem jego zadań. Wskazana regulacja prawna czasu pracy tej grupy zawodowej obowiązuje już od wielu lat i przewidywał ją również art. 68 ustawy z dn. 20 czerwca 1985 r. - Prawo o ustroju sądów powszechnych (Dz.U. 1985, nr 31, poz. 137), a wcześniej przepis art. 65 rozporządzenia Prezydenta RP z dn. 6 lutego 1928 r. - Prawo o ustroju sądów powszechnych (Dz.U. 1928, nr 12, poz. 93 - przepis został wprowadzony na mocy dekretu Rady Państwa z dn. 27 grudnia 1974 r. o zmianie Prawa o ustroju sądów powszechnych, Dz.U. 1974, nr 50, poz. 316; zob. także art. 77-80 
tzw. konstytucji marcowej z dn. 17 marca 1921 r., Dz.U. 1921, nr 44, poz. 267). Powyższe unormowanie jest lakoniczne i może wydawać się jednoznaczne, albowiem zazwyczaj wywołuje skojarzenie z kodeksowym systemem zadaniowego czasu pracy (art. 140 k.p.). Tymczasem powstaje zasadnicze pytanie, czy czas pracy sędziów uregulowany w art. 83 pragmatyki jest rzeczywiście tożsamy - względnie istotnie zbliżony - do systemu zadaniowego czasu pracy uregulowanego w art. 140 k.p. Dla porządku przypomnieć należy brzmienie tego drugiego przepisu. Otóż w przypadkach uzasadnionych rodzajem pracy lub jej organizacją albo miejscem wykonywania pracy może być stosowany system zadaniowego czasu pracy. Pracodawca, po porozumieniu z pracownikiem, ustala czas niezbędny do wykonania powierzonych zadań, uwzględniając wymiar czasu pracy wynikający z norm określonych w art. 129 k.p. Do pełniejszego zrozumienia dalszych rozważań konieczne jest choćby krótkie przypomnienie istoty zadaniowego czasu pracy.

System zadaniowego czasu pracy jest jednym ze szczególnych systemów czasu pracy uregulowanym w Kodeksie pracy. Zadaniowy czas pracy dotyczy tych wyjątkowych sytuacji, w których pracownik, wykonując pracę, nie jest objęty normami czasu pracy i faktycznie pozostaje poza możliwą i realną kontrolą pracodawcy (Muszalski 2001, s. 29; Sobczyk 2005, s. 191 i n.). Istotą systemu zadaniowego jest rezygnacja z bezpośredniego posługiwania się normami czasu pracy, a miernikiem pozostawania pracownika w dyspozycji pracodawcy staje się wymiar zadań przydzielonych mu do wykonania (Driczinski 2001, s. 17; uzasadnienie wyroku SN z 19 listopada 2003 r., I PK 476/02, OSNP 2004, nr 22, poz. 382). Samodzielność pracownika nie oznacza tutaj braku podporządkowania kierownictwu pracodawcy, ale to, że będzie on mógł sam zdecydować, kiedy i z jaką intensywnością wykona wyznaczone mu zadania. System zadaniowy najczęściej występuje wtedy, gdy praca jest wykonywana poza zakładem pracy, a pracodawca nie ma możliwości bezpośredniego kontrolowania świadczenia pracy przez pracownika, względnie jest to nadmiernie utrudnione lub ekonomicznie nieracjonalne oraz zostaje wyłączona możliwość prowadzenia rzeczywistej ewidencji czasu pracy (Bury 2007, s. 141). W systemie zadaniowego czasu pracy pracodawca, po porozumieniu z pracownikiem, ustala czas niezbędny do wykonania zleconych zadań, uwzględniając wymiar czasu pracy wynikający z norm określonych w art. 129 k.p. (Stanibuła 2005, s. 26). Oznacza to, że powierzone pracownikowi do wykonania zadania powinny być tak ustalone, aby ich realizacja mogła nastąpić w granicach podstawowej normy czasu pracy, przy dołożeniu przeciętnej staranności i sumienności pracownika.

Niedostosowanie wymiaru zadań pracownika do norm czasu pracy stanowi naruszenie przepisów o czasie pracy i uzasadnia roszczenie pracownika o ustalenie wynagrodzenia faktycznie odpowiadającego wykonanej pracy, z uwzględnieniem dodatku za pracę w godzinach nadliczbowych. Jeżeli jest wiadome, że powierzonego zadania nie będzie można wykonać w czasie ośmiogodzinnej dniówki roboczej i przeciętnie czterdziestogodzinnej tygodniowej normy czasu pracy, niedopuszczalne jest stosowanie tej techniki do rozliczania czasu pracy pracowników. Zadaniowy system czasu pracy jest więc dopuszczalny w tych sytuacjach, w których istnieje możliwość dostosowania wymiaru zadań pracownika do norm czasu pracy. Pracownik jest bowiem rozliczany nie 
z liczby przepracowanych godzin, ale z liczby wykonanych zadań. Zaletą tego systemu jest to, że umożliwia harmonijne godzenie interesów pracownika i pracodawcy. Interes pracodawcy jest realizowany przez wykonanie powierzonych zadań, a interes pracownika przez swobodne podejmowanie decyzji o tym, kiedy, jak i gdzie będzie wykonywał te zadania (Rączka 2004, s. 15). Z tym systemem czasu pracy wiąże się jednak pewne niebezpieczeństwo dla pracownika. Mianowicie pracodawca może ustalać, że czas pracy pracownika ma charakter zadaniowy w celu uniknięcia kosztów związanych z godzinami nadliczbowymi i wyeliminowania wielu rygorystycznych ograniczeń, jakie stwarzają przepisy działu VI Kodeksu. W ten sposób, w przypadkach pozostawania pracownika w pełnej dyspozycyjności przełożonego, wielu pracodawców wymusza nieopłacaną dodatkowo pracę ponad obowiązujący wymiar czasu pracy. Skala tego zjawiska jest $\mathrm{z}$ reguły trudno rozpoznawalna. Taka praktyka oznacza oczywiście przekreślenie walorów normalnego systemu czasu pracy, w którym rytm pracy jest ustalony w znanym pracownikowi rozkładzie czasu pracy (uzasadnienie postanowienia SN z 7 grudnia 1999 r., I PKN 427/99, OSNAPiUS 2001, nr 8, poz. 274; wyrok SN z 12 stycznia 1999 r., I PKN 526/98, OSNAPiUS 2000, nr 4, poz. 147; Muszalski 2001, s. 29).

Jak wynika z literalnej treści art. 83 pragmatyki, ustawodawca nie nazywa czasu pracy sędziów wprost systemem zadaniowym, jak to czyni art. 140 k.p., wskazuje natomiast na czas określony wymiarem zadań sędziego. Powstaje jednak pytanie, czy te nieznaczne, moim zdaniem, różnice semantyczne przesądzają o istnieniu odmiennych modeli czasu pracy; inaczej rzecz ujmując, czy w art. 83 ustawy ustawodawca wprowadził nowy model, nieznany przepisom powszechnego prawa pracy, i tym samym wzbogacił jego instytucje.

Powyższa okoliczność ma istotne znaczenie. Dopiero bowiem w przypadku ustalenia, że pracownika obowiązuje zadaniowy czas pracy, na wzór art. 140 k.p., zasadne jest czynienie dalszych ustaleń co do rozmiaru obowiązujących sędziego zadań, w szczególności możliwości ich wykonania w ramach norm czasu pracy. W przypadku zlecenia sędziemu zadań niemożliwych do wykonania w ramach norm czasu pracy określonych w art. 129 k.p. może mu przysługiwać roszczenie o ustalenie prawidłowego (obniżonego) wymiaru zadań i zasądzenie wyrównania wynagrodzenia do odpowiadającego wykonanej pracy.

\section{Poglądy na temat modelu czasu pracy sędziów}

Od kilku lat prezentuję niezmienny pogląd (Bury 2009, s. 608 i n.; 2013, s. 383 i n.; por. Iwulski 2002, s. 235), że w odniesieniu do sędziów jako kategorii pracowników mianowanych ustawodawca wprowadził, na wzór art. 140 k.p., system zadaniowego czasu pracy z wszelkimi tego konsekwencjami. W związku z tym pracodawca - sąd zatrudniający sędziego - ustalając wymiar zadań i czas niezbędny do ich wykonania, powinien uwzględniać wymiar czasu pracy wynikający z norm określonych w art. 129 k.p. Zadania powierzone pracownikowi sędziemu do wykonania powinny być zatem tak ustalone, aby ich realizacja mogła nastąpić w granicach podstawowej normy czasu pracy, przy dołożeniu przeciętnej staranności i sumienności pracownika. Ustalenie zadań na 
poziomie wyższym, tj. niemożliwym do wykonania w granicach podstawowej normy czasu pracy (art. 129 k.p.), stanowi naruszenie przepisów o czasie pracy. Z powyższego wynika, iż sędzia nie ma obowiązku przepracowania określonej liczby dni w tygodniu oraz rozpoczynania i kończenia pracy o określonych godzinach. Wielkość powierzonych mu zadań powinna być jednak zobiektywizowana i odniesiona do poziomu jego kwalifikacji i umiejętności. Sędzia, który nie reprezentuje odpowiedniego poziomu umiejętności organizowania pracy i wiedzy zawodowej, musi poświęcić na pracę znacznie więcej czasu - albo wykonuje mniej zadań, a wtedy może być to oceniane negatywnie, a w skrajnych przypadkach uznane za przewinienie dyscyplinarne.

Z tych względów system zadaniowy stanowi zarazem bodziec do podnoszenia przez sędziów poziomu kwalifikacji i umiejętności (Bury 2009, s. 608 i n.; 2013). Ta ostatnia kwestia budzi najwięcej kontrowersji oraz wątpliwości, rodzi również trudności techniczne w zakresie pomiaru tych wektorów. Zgodnie z wyrokiem Sądu Najwyższego z 4 listopada 2004 r. (SNO 44/04, niepubl.):

[...] wynikająca $z$ art. 83 ustawy możliwość wykonywania pracy przez sędziego w zasadzie w dowolnym czasie i nie tylko w budynku sądu doznaje jednak ograniczeń ze względu na rodzaj służbowych zadań. Jest oczywiste, że przeprowadzenie rozprawy musi się odbyć w oznaczonym z góry czasie i miejscu - na ogół w budynku sądu [...]. Poza tym w niektórych sytuacjach czynności objęte zakresem zadań sędziowie muszą wykonywać codziennie (w dni robocze) i w budynku sądu, ponieważ tylko funkcjonując w ten sposób, mogą realizować powierzone im zadania. Dotyczy to w szczególności sędziów pełniących służbę w wydziałach, do których wpływa bardzo duża liczba nieobszernych spraw wymagających szybkiego rozstrzygnięcia. Zapoznanie się przez sędziego z dużą liczbą takich spraw i szybkie podejmowanie w nich rozstrzygnięć jest możliwe jedynie pod warunkiem codziennej obecności w budynku sądu w dni robocze [...]. Wtedy można przyjąć, że świadczył on pracę w wymiarze odpowiadającym zakresowi jego zadań służbowych (Rycak 2009, s. 239 i n.).

Nie do zaakceptowania jest z pewnością pogląd, aby pracodawca sędziego miał - na podstawie art. 83 pragmatyki - nieskrępowaną i nieobwarowaną żadnymi konsekwencjami dowolność w nakładaniu na sędziego obowiązków pracowniczych.

Należy zwrócić uwagę, że pogląd o swobodzie towarzyszącej sędziemu przy organizowaniu czasu pracy i jego dość dużej decyzyjności w zakresie sposobu gospodarowania nim jest nieuprawniony. Zdaje się bowiem wynikać z niego, że zadaniowy czas pracy jest dobrodziejstwem i rodzi jakieś uprzywilejowanie pozycji sędziego. Tymczasem art. 83 pragmatyki należy powiązać z treścią innych przepisów tej ustawy. I tak prezes sądu jest zwierzchnikiem służbowym sędziów danego sądu (art. $22 \$ 1$ ust. 1 lit. b), a sędzia nie może, powołując się na zasadę niezawisłości sędziowskiej, uchylić się od wykonania poleceń w zakresie czynności administracyjnych, jeżeli z mocy przepisów ustawy należą do obowiązków sędziowskich, a także poleceń dotyczących sprawności postępowania sądowego; może jednak domagać się wydania polecenia na piśmie (art. 79).

Powyższa regulacja znajduje również szczegółowe rozwinięcie w przepisach rozporządzenia Ministra Sprawiedliwości - Regulaminu urzędowania sądów powszechnych 
z dn. 23 grudnia 2015 r. (Dz.U. 2015, poz. 2316, dalej: „Regulamin”). I tak zgodnie $\mathrm{z} \$ \$ 40-41$ Regulaminu prezes sądu ustala godziny urzędowania sądu i godziny przyjęć interesantów. W razie potrzeby może zarządzić dwuzmianowy system urzędowania sądu. Prezes sądu, wiceprezes, a także inne osoby pełniące funkcje lub osoby wyznaczone przez prezesa sądu w godzinach urzędowania sądu powinny przebywać $\mathrm{w}$ siedzibie sądu. W związku z tym tzw. sędziowie funkcyjni poza czasem przeznaczonym na realizację czynności orzeczniczych pełnią dodatkowo funkcje administracyjne, wymagające od nich obecności w określonym czasie i miejscu. W ten sposób ich zatrudnienie można określić - w zakresie formuły czasowej - jako pracę w podstawowym systemie czasu pracy z elementami modelu zadaniowego (w zakresie sfery orzeczniczej: Rycak 2009, s. 239 i n.).

Poza wyżej wskazanymi obowiązkami, które można by określić mianem podstawowych i składających się na istotę pracę sędziego, sędziowie wykonują wiele dodatkowych czynności, w tym pełnią dyżury i realizują zastępstwa ( $\$$ 52b i 361 Regulaminu). Pamiętać również należy, w kontekście dyspozycyjności czasowej sędziów, o treści art. $47 \mathrm{~b}$ ust. 1 pragmatyki, z której wynika zasada niezmienności składu orzekającego, mianowicie zmiana składu sądu może nastąpić tylko w przypadku niemożności rozpoznania sprawy w dotychczasowym składzie albo długotrwałej przeszkody w rozpoznaniu sprawy w dotychczasowym składzie.

Zdecydowanie należy podkreślić, że system zadaniowy dopuszcza okresy spiętrzenia pracy czy też nadmiaru zadań do wykonania, wówczas sędzia musi tak zorganizować pracę, aby je bez zbędnej zwłoki wykonać. Nie można jednak akceptować stanu, w którym praca ponadwymiarowa staje się stałym elementem organizacji pracy sędziego, czymś normalnym, towarzyszącym każdego dnia - czyli stanu, któremu nie można nadać przymiotu przejściowego. W wielu sądach regularnie się zdarza, że sędzia wykonuje pracę polegającą na sporządzaniu uzasadnień czy też przygotowywaniu się do sesji codziennie, $w$ tym również w dni wolne od pracy. Nie bez znaczenia pozostają problemy kadrowe, z którymi boryka się wiele sądów. Wynikają one z nieobsadzonych stanowisk sędziowskich, a także z absencji sędziów, często długotrwałych. To powoduje konieczność podziału referatów sędziów nieobecnych oraz dekretowanie bieżącego wpływu - w istocie zwiększonego - na sędziów obecnych.

Z powyższego wynika, że zakres zadań powierzonych sędziom znacznie wykracza poza typowe obowiązki orzecznicze wykonywane w "normalnym” czasie pracy, nie wspominając już o rzekomej swobodzie mającej towarzyszyć sędziom w ich wykonywaniu co do zasady oraz czasokresu. Ten zmodyfikowany zakres podporządkowania pracowniczego, pomijający sferę orzeczniczą pracy sędziego, nie oznacza, że nie pozostaje on w dyspozycji pracodawcy. Taki wniosek pozostawałby w sprzeczności z istotą stosunku pracy. Bardzo często wskazuje się, że w zadaniowym systemie czasu pracy z reguły pracownik sam decyduje, w jakich godzinach będzie wykonywał pracę i z jaką intensywnością. Wiele zadań sędzia może wykonywać i faktycznie wykonuje poza siedzibą sądu i poza godzinami pracy sekretariatów sądu - obejmuje to na przykład przygotowanie się do rozpoznania i rozstrzygnięcia sprawy, studiowanie literatury prawniczej, zapoznanie się 
z poglądami doktryny i orzecznictwem sądowym, opracowanie pisemnych motywów rozstrzygnięcia. Podnosi się, że to sędzia jest współodpowiedzialny za prawidłową organizację swojej pracy, wobec czego nie może w prosty sposób usprawiedliwiać niewykonywania jednego ze swoich podstawowych obowiązków wynikającego z podziału czynności wykonywaniem zadań orzeczniczych w innej kategorii spraw. Tymczasem powyższe nie tylko nie odpowiada w pełni rodzajom obowiązków sędziego, zwłaszcza dodatkowych, ponieważ w wielu przypadkach trudno mówić, aby sędzia miał rzeczywistą swobodę w wyznaczaniu godzin pracy i miał wpływ na jej intensywność, ale też jednocześnie występuje w takim rozmiarze, że nawet gdyby czynności te były realizowane w siedzibie sądu, nie mogłyby być wykonane w tzw. normalnym czasie pracy. Nie bez znaczenia pozostaje okoliczność, że praca sędziów odbywa się w warunkach swoistej presji społecznej związanej z negatywną oceną pracy wymiaru sprawiedliwości, która wywołuje swoiste poczucie konieczności załatwiania spraw szybko oraz w większej liczbie. Powyższe refleksje nie niweczą, moim zdaniem, koncepcji, że czas pracy sędziego można określić mianem zadaniowego. Ten model organizacji czasu pracy najpełniej odzwierciedla istotę pracy sędziego i nie istnieje jednocześnie inny system czasu pracy, który mógłby znaleźć w tym przypadku - jako bardziej odpowiedni - zastosowanie. Brak jest bowiem podstaw do przyjęcia, aby w stosunku do tej kategorii zawodowej ustawodawca zdecydował się na wprowadzenie nowego specyficznego systemu czasu pracy, nieznanego przepisom Kodeksu.

Powyższe stanowisko nie jest jednolite i w literaturze przedmiotu podkreśla się występowanie w odniesieniu do sędziów specyficznego modelu czasu pracy, odmiennego od uregulowanego w art. 140 k.p. Takie założenie wyklucza stosowanie innych przepisów Kodeksu pracy, w tym art. $129 \$ 1$ k.p. oraz art. 151 i n. k.p. W omawianym zakresie można odnotować jeszcze jeden pogląd. Według Artura Rycaka (2009, s. 239) sędziowie sądów powszechnych, poza sędziami funkcyjnymi, pracują w mieszanej formule zatrudnienia, którą można by określić jako czasowo-zadaniową.

Wojciech Muszalski (2001, s. 28 i n.) zaprezentował pogląd, że charakter pracy sędziów w ogóle nie uzasadnia objęcia tej grupy zawodowej zadaniowym czasem pracy. Z kolei według Tadeusza Nycza (2004, s. 66 i n.) i Arkadiusza Sobczyka (2005, s. 197) nie występuje analogia pomiędzy regulacjami w zakresie określania czasu pracy sędziów oraz art. 140 k.p. U podstaw przesłanek regulacji w zakresie czasu pracy dla tej kategorii pracowników leży bowiem usunięcie kolizji pomiędzy koniecznością realizacji istotnych interesów społecznych a ochronnymi przepisami w zakresie czasu pracy. Jeżeli chodzi o zadania sędziego (a także prokuratora), to ich dynamika i nieobliczalność rozwoju, a równocześnie określone obowiązki państwa w zakresie gwarantowania praworządności powodują, że nie mogą być one ujęte w sztywne ramy czasu pracy. Precyzyjniej: mogłyby one być z punktu widzenia technicznego ujęte w ten sposób, jednak pozostawałoby to w sprzeczności ze społecznymi oczekiwaniami w stosunku do reprezentowanych przez nich instytucji. Autorzy sformułowali wniosek, że w odniesieniu do wskazanych pracowników trudno w ogóle mówić o systemie zadaniowym w rozumieniu planowania zadań. Do sędziów nie ma zastosowania art. 140 zd. 2 k.p., który przewiduje ustalenie 
przez pracodawcę, po porozumieniu z pracownikiem, czasu niezbędnego do wykonania powierzonych mu zadań, z uwzględnieniem wymiaru czasu pracy wynikającego z norm określonych $\mathrm{w}$ art. $129 \$ 1$ k.p. W odniesieniu do sędziego nie następuje uzgodnienie $\mathrm{z}$ nim (ustalenie po porozumieniu $\mathrm{z}$ nim) czasu niezbędnego do wykonania powierzonych mu zadań.

Według Katarzyny Gonery (2013), biorąc pod uwagę specyfikę pracy sędziego i rodzaj powierzonych mu zadań, ustawodawca stworzył szczególny model czasu pracy sędziego, który dopuszcza odstępstwa od ogólnych reguł ujętych w przepisach Kodeksu pracy. Regulacja zawarta w art. 83 pragmatyki nie przewiduje możliwości precyzyjnego określenia ilościowego wymiaru zadań, na przykład w wymiarze miesięcznym (tzw. pensum), ani indywidualizacji wysokości wynagrodzenia w zależności od wymiaru obowiązków sędziego. Sędzia nie pozostaje „w dyspozycji pracodawcy”, na ogół sam decyduje o czasie wykonania powierzonych mu zadań. Może je wykonywać (np. sporządzać pisemne uzasadnienia orzeczeń) w dowolnym czasie i miejscu, z wyjątkiem tych czynności, których czas i miejsce są determinowane przez ich rodzaj (np. przeprowadzenie rozprawy, pełnienie dyżuru). Pracy sędziego nie można ściśle wymierzyć w jednostkach czasu (nie da się np. wymierzyć pracy intelektualnej polegającej na wypracowaniu koncepcji rozstrzygnięcia sprawy). Najważniejszą przyczyną braku związania sędziów ściśle określonym czasem pracy jest samodzielność ich działania oraz ustrojowa niezależność, mające oparcie w przepisach Konstytucji RP z dn. 2 kwietnia 1997 r. (Dz.U. 1997, nr 78, poz. 483 ze zm.). Stanowiąc, że czas pracy sędziego jest określony wymiarem jego zadań, komentowany przepis nie odsyła do żadnych norm czasu pracy ani jego wymiaru, nie nawiązuje też do treści art. 140 k.p.

Analogiczny pogląd zaprezentowała również Małgorzata Kurzynoga (2011, s. 232), wskazując dodatkowo, że kodeksowy system zadaniowego czasu pracy jest wprowadzany odmiennie (art. 150 k.p.) niż czas pracy sędziów - o jego modelu przesądził bowiem akt rangi ustawowej. Dodatkowo w art. 83 pragmatyki nie ma odesłania, na wzór art. 140 zd. 2 k.p., do norm czasu pracy. Sędziowska pragmatyka pracownicza w zakresie art. 83 jest w konsekwencji zupełna i zamknięta, regulując specyficzny system czasu pracy, nieznany Kodeksowi pracy.

Zwolennicy powyższego poglądu zwracają uwagę, że sędziowie jako grupa zawodowa należą do państwowej służby publicznej, co wiąże się z ich działalnością w ramach państwa i wykonywaniem specyficznych dla państwa funkcji - w tym przypadku wymierzania sprawiedliwości. Jednocześnie oznacza to, że ustawa szczególna - Prawo o ustroju sądów powszechnych - może odmiennie unormować status prawny sędziego jako pracownika niż czyni to Kodeks pracy w ramach powszechnego prawa pracy. Odrębna regulacja dotyczy z jednej strony większej odpowiedzialności i znaczącej wagi obowiązków przypisanych do stanowiska sędziego, z drugiej zaś ujawnia się w stabilizacji zatrudnienia, otrzymywaniu za czas choroby wynagrodzenia, dodatkowym urlopie wypoczynkowym, urlopie dla poratowania zdrowia, wreszcie w przechodzeniu w stan spoczynku i otrzymywaniu z tego tytułu uposażenia poza powszechnym systemem ubezpieczenia społecznego na wypadek starości lub niezdolności do pracy. Autorzy 
prezentujący powyższy pogląd zwracają jednak uwagę, że obowiązująca regulacja czasu pracy sędziów nie stanowi przyzwolenia na nieustanne i nieograniczone zwiększanie zakresu obowiązków sędziów bez prawa do wypoczynku, a eliminowanie takich zagrożeń jest sytuacją pożądaną i oczywistą.

\section{Model czasu pracy sędziego w świetle orzecznictwa Sądu Najwyższego i Trybunału Konstytucyjnego}

Omawiana problematyka była przedmiotem wypowiedzi orzeczniczych. Spośród stosunkowo nielicznych należy wymienić uchwałę Sądu Najwyższego z 8 kwietnia 2009 r. (II PZP 2/09, BSN 2009, nr 4, poz. 27; Bury 2009, s. 608 i n.) oraz wyrok Trybunału Konstytucyjnego z 7 maja 2013 r. (SK 11/11, OTK-A 2013, nr 4, poz. 40; Bury 2013, s. 383 i n.).

W wyżej wymienionej uchwale Sąd Najwyższy stwierdził, że „sędziemu sądu powszechnego nie przysługuje dodatkowe wynagrodzenie na zasadach wynikających $\mathrm{z}$ art. $151^{1}$ k.p. w razie świadczenia pracy w rozmiarze wykraczającym poza normy czasu pracy ustanowione w art. $129 \$ 1$ k.p." Opowiedział się tym samym za istnieniem w odniesieniu do sędziów odrębnego od kodeksowego modelu czasu pracy, z wyłączeniem art. 140 k.p. oraz norm czasu pracy wynikających z art. $129 \$ 1$ k.p. Do takiego wniosku upoważnia nie tylko analiza treści art. 83 ustawy, ale również ocena statusu prawnego sędziego.

Powyższy pogląd został powtórzony w wyroku z 15 września 2015 r. (III KRS 49/15, LEX nr 2288956; por. postanowienie SN z 27 sierpnia 2015 r., SNO 47/15, LEX nr 1809890). I tak Sąd Najwyższy argumentował, że istotne znaczenie ma czas pracy sędziego określony wymiarem jego zadań, co w praktyce oznacza, że z jednej strony sędzia nie ma obowiązku pracy w oznaczonych godzinach przez określoną liczbę dni w tygodniu i może wykonywać pracę w zasadzie w dowolnym czasie i nie tylko w budynku sądu, z drugiej zaś że nałożone zadania wymuszają pracę w godzinach urzędowania sądów (zaplanowane czynności procesowe) i jednocześnie poza nimi (zapoznawanie się z aktami spraw, sporządzanie uzasadnień orzeczeń), także w dni wolne od pracy, niedziele, a nawet święta. Odpowiednio do tego sędziego rozlicza się z wykonania czynności objętych zakresem jego zadań, a więc znaczenie ma sprawność postępowania i terminowość podejmowanych czynności, niezbędna przede wszystkim z punktu widzenia sprawnego działania wymiaru sprawiedliwości, podlegająca nie tylko okresowej, ale i bieżącej ocenie przełożonych. Z kolei sprawność warsztatu sędziego, od którego uzależniona jest sprawność postępowania i terminowość podejmowanych czynności, zależy zarówno od jego profesjonalnej wiedzy prawniczej, zdolności intelektualnych i pracowitości, jak też od możliwości korzystania w pracy z nowoczesnych technologii.

Moim zdaniem, za niepokojące należy uznać stanowisko zawarte w wyroku z 12 listopada 2003 r. (SNO 71/03, LEX nr 470253), w którym Sąd Najwyższy wskazał, że może się zdarzyć - i w praktyce nierzadko się zdarza - że wielkość powierzonych sędziemu zadań uniemożliwia ich wykonanie w godzinach urzędowania. Obowiązkiem kierownictwa 
sądu jest ułatwianie sędziemu wykonywania pracy również poza czasem urzędowania sądu. Zgłoszenie przez sędziego potrzeby korzystania z programu komputerowego, także po godzinach urzędowania sądu, nie tylko nie jest zdumiewające i bezprecedensowe, ale przeciwnie, wydaje się czymś naturalnym. Powyższe orzeczenie akcentuje, jak się wydaje, że niemożność wykonania przez sędziego zadań w godzinach urzędowania sądu zdarza się nierzadko, jednocześnie motywując kierownictwo sądów do umożliwienia sędziemu świadczenia pracy poza tymi godzinami, traktując je jako zjawisko normalne, a nie nadzwyczajne.

Sąd Najwyższy przyjął również, że punktem odniesienia dla ustalenia zakresu obowiązków sędziego powinny być realne potrzeby wynikające z bieżącej sytuacji w konkretnej jednostce organizacyjnej wymiaru sprawiedliwości. Wskazywał na usprawiedliwione czasowe zwiększenie zakresu obowiązków z powodu dłuższej niedyspozycji innego sędziego, podając, że:

[...] nie są to zjawiska nadzwyczajne i ich naturalną konsekwencją jest okresowe zwiększenie obowiązków orzeczniczych pozostałych sędziów, którzy przejmują w ustalonym zakresie - pozostawiony referat. Każdy sędzia może znaleźć się w takiej sytuacji, a w ramach swojego szczególnego statusu musi liczyć się z koniecznością okresowego podjęcia dodatkowego wysiłku orzeczniczego, zapewniającego stabilne realizowanie zadań jakie stoją przed tym konkretnym sądem, w którym pełni służbę (wyrok SN z 17 maja 2016 r., SNO 10/16, LEX nr 2053645).

Kwestia zgodności art. 83 pragmatyki z Konstytucją RP była przedmiotem postępowania przed Trybunałem Konstytucyjnym w sprawie ze skargi wniesionej przez sędziego (SK 11/11, OTK-A 2013, nr 4, poz. 40). Wnoszący skargę konstytucyjną zarzucił, że art. 83 i art. $91 \$ 1$ ustawy są niezgodne z Konstytucją RP o tyle, o ile nie ustalają maksymalnych norm czasu pracy sędziego sądu powszechnego, nie określają precyzyjnie sytuacji, w jakich dopuszczalne jest ich przekroczenie, i wyłączają prawo do rekompensaty $w$ postaci dodatkowego wynagrodzenia lub ekwiwalentnego czasu wolnego od pracy za świadczenie pracy $\mathrm{w}$ rozmiarze wykraczającym ponad takie normy. Wyżej wymienionym wyrokiem z 7 maja 2013 r. (SK 11/11, OTK-A 2013, nr 4, poz. 40) Trybunał Konstytucyjny orzekł, że art. 83 pragmatyki jest zgodny z art. 66 w zw. $\mathrm{z}$ art. 24 Konstytucji RP oraz nie jest niezgodny z art. $30 \mathrm{i}$ art. $47 \mathrm{w}$ zw. $\mathrm{z}$ art. 71 ust. 1 Konstytucji. Stwierdził przy tym, że poddany kontroli przepis nie zawiera odesłań do żadnych norm czasu pracy. Nie przewiduje ani możliwości ilościowego określenia wymiaru zadań, ani indywidualizacji wysokości wynagrodzenia w zależności od rzeczywistego wymiaru obowiązków sędziego. Sędzia nie pozostaje także w dyspozycji pracodawcy, tylko sam ustala czas potrzebny do wykonania powierzonych mu zadań. Może wykonywać swoją pracę w dowolnym czasie i miejscu, poza czynnościami, które ze swojej istoty wymagają przebywania w określonym miejscu i czasie, takich jak na przykład przeprowadzanie rozpraw czy pełnienie dyżurów. Czas pracy sędziego nie podlega kontroli ani ewidencji, a sędziego rozlicza się z wykonania czynności objętych zakresem jego zadań. 
W wypadku sędziów obowiązująca regulacja czasu pracy mieści się w zakresie swobody regulacyjnej ustawodawcy. Stanowi ona historycznie ukształtowany, odrębny system, który wynika ze szczególnego charakteru wykonywanej przez sędziów pracy i specyfiki jej organizacji. Sprawowanie urzędu sędziego jest służbą publiczną, która charakteryzuje się dużą odpowiedzialnością w związku z wykonywanymi obowiązkami, a odpowiedzialność ta kompensowana jest szczególnymi uprawnieniami zastrzeżonymi dla tej grupy zawodowej. Przyjęta regulacja daje możliwość elastycznego organizowania pracy, zgodnie z indywidualnymi predyspozycjami sędziego. Sędzia nie podlega bowiem ścisłej kontroli pracodawcy, który - co istotne - nie prowadzi ewidencji czasu pracy. W systemie czasu pracy sędziego nie ma wymogu dostosowania wymiaru zadań czy możliwości ich realizacji do jakichkolwiek norm czasu pracy. Sędzia nie jest więc zobowiązany do dokładnego rozliczania się z pracodawcą z wykonanych przez siebie obowiązków. To od właściwości i charakteru zadania, a także od poziomu kwalifikacji zawodowych i umiejętności organizacji pracy sędziego, a nie od pracodawcy, zależy czas jego wykonania. Ogranicza to wpływ pracodawcy na sposób orzekania sędziego, a to $\mathrm{z}$ kolei sprzyja niezawisłości sędziego w sprawowaniu urzędu. Powyższy wyrok wkomponowuje się we wcześniejsze orzecznictwo Trybunału, z którego wynika, że ustawodawca ma swobodę określenia systemu pracy określonych grup zawodowych, a odejście w kwestii czasu pracy sędziów od ogólnego rozwiązania przyjętego w Kodeksie pracy na rzecz odrębnej regulacji zamieszczonej w pragmatyce służbowej mieści się w zakresie swobody regulacyjnej, która mu przysługuje (wyrok TK z 24 lutego 2004 r., K 54/02, OTK-A 2004, nr 2, poz. 10).

Moim zdaniem, nie można zgodzić się z Trybunałem, że sędzia, którego prawo do odpoczynku podlega naruszeniu, może sięgnąć po możliwość przewidzianą w art. 281 pkt 5 k.p., ewentualnie dochodzić roszczeń na podstawie przepisów prawa cywilnego (art. 443 ustawy z dn. 23 kwietnia 1964 r. - Kodeks cywilny, Dz.U. 2019, poz. 1145 tekst jedn. w zw. z art. 300 k.p.). Rozwiązania te nie wydają się wystarczające, zwłaszcza że rekomenduje się jednocześnie swoistą powściągliwość w sięganiu po powyższe roszczenia.

\section{Podsumowanie}

Biorąc pod uwagę szczególny charakter sprawowania urzędu sędziego, nie znajduje, moim zdaniem, racjonalnego uzasadnienia pogląd, że system organizacji czasu pracy sędziów określony w art. 83 pragmatyki nie może być odnoszony do norm czasu pracy z art. 129 $\$ 1$ k.p., zwłaszcza gdy sędziemu powierza się zadania i czynności niewykonalne z różnych względów w tzw. normalnym czasie pracy. Wniosek przeciwny oznaczałby, że do sędziów nie znajduje zastosowania art. 6b Dyrektywy Parlamentu Europejskiego i Rady 2003/88/EC z dn. 4 listopada 2003 r. (Dz.Urz. UE L 2003, nr 299), dotyczącej niektórych aspektów organizacji czasu pracy, w którym został ustanowiony maksymalny tygodniowy czas pracy w wymiarze przeciętnie 48 godzin, łącznie z godzinami nadliczbowymi. Tym samym sędziemu przysługuje w każdej dobie prawo do co najmniej jedenastu godzin 
i w każdym tygodniu prawo do co najmniej 35 godzin nieprzerwanego odpoczynku (wyrok SN z 26 czerwca 2014 r., SNO 3/14, LEX nr 1504850).

Pozwala to na wyprowadzenie wniosku, że jeżeli nie normy, to właśnie okresy odpoczynku czynią system czasu pracy sędziów „wymiernym” i „normowanym”. Obowiązki nałożone na sędziego można zatem uznać za możliwe do wykonania w obowiązującym go czasie pracy, jeżeli ich realizacja w poszczególnych dobach i tygodniach nie odbywa się kosztem minimalnych okresów odpoczynku (wyrok SN z 22 czerwca 2015 r., SNO 36/15, LEX nr 1755918; Kurzynoga 2011, s. 235-237; Haÿduk-Hawrylak i in. 2018, s. 277-278), zwłaszcza że stan ten jest powiązany z brakiem możliwości ubiegania się o rekompensatę za pracę w godzinach nadliczbowych (wyrok ETS z 8 lutego 2001 r., C-350/99, Wolfgang Lange p. Georg Schüneman sp. z o.o.; wyrok ETS z 1 grudnia 2005 r., C-14/04, Dellas; postanowienie ETS z 11 stycznia 2007 r., C-437/05, Vorel). Jak pokazuje rzeczywistość, powyższe okresy zagwarantowanego odpoczynku są fikcją, w sytuacji stałej, a nie jedynie okresowej/epizodycznej pracy wykonywanej przez sędziów popołudniami oraz w dni wolne od pracy. Wprawdzie na kierownictwie sądu spoczywa obowiązek takiego zorganizowania pracy, aby sędzia mógł realizować wszystkie przekazane mu zadania bez konieczności wyboru między pilniejszymi i mniej pilnymi, jednakże i to założenie nie wytrzymuje konfrontacji $\mathrm{z}$ realiami funkcjonowania sędziów i sądów.

W przypadku założenia, że art. 83 pragmatyki nie przewiduje zadaniowego czasu pracy, powstaje pytanie, jaki system (model organizacji czasu pracy) znajduje zastosowanie do sędziów i jak jednocześnie nazwać ten uregulowany w art. 83. Trudno bowiem przyjąć, aby w stosunku do omawianej grupy zawodowej ustawodawca zastosował specyficzny system czasu pracy, opisując go jednocześnie w zasadniczych elementach w sposób charakterystyczny dla systemu zadaniowego.

W konsekwencji należy przyjąć, że art. 83 pragmatyki reguluje czas pracy sędziów w sposób niepełny i nie wyklucza stosowania - w zakresie nim nieuregulowanym przepisów Kodeksu pracy. Powyższego wniosku nie niweczy to, że czas pracy sędziego nie jest normowany godzinowo, lecz wymiarem zadań. Moim zdaniem, lakoniczne brzmienie art. 83 i pominięcie odesłania do norm i wymiaru czasu pracy (w porównaniu $\mathrm{z}$ art. 140 k.p.) o niczym w tym względzie nie przesądza i umacnia tezę o posiłkowym stosowaniu przepisów kodeksowych. W tym miejscu należy również przypomnieć, że regulacja czasu pracy zawarta w dziale VI k.p. jest niezwykle rozbudowana i zawiera niejako „wyjściowe” unormowanie instytucji, do których odnoszą się i którymi posługują się wielokrotnie pragmatyki pracownicze i służbowe (np. okresy odpoczynku, dyżur, praca w porze nocnej czy praca w godzinach nadliczbowych).

Nie ulega wątpliwości, iż pomimo że sędziowie mają pewien szczególny status prawny, a ich zatrudnienie cechuje specyfika w porównaniu $\mathrm{z}$ tzw. powszechnym zatrudnieniem, w dalszym ciągu pozostają - jak wiele innych - grupą zawodową, po prostu pracownikami w rozumieniu art. 2 k.p. Podkreślenia wymaga w tym miejscu, że ratio legis przepisów dotyczących czasu pracy, w tym przekraczania dobowych i tygodniowych norm czasu pracy, polega na tym, że powinny one spełniać przede 
wszystkim funkcję ochronną. Chodzi głównie o ochronę zdrowia pracownika jako dobra wyższej wartości od nadmiernego wysiłku podjętego kosztem czasu przeznaczonego na wypoczynek (Małysz 1979, s. 60; uchwała pełnego składu Izby Pracy i Ubezpieczeń Społecznych z 4 czerwca 1971 r., III PZP 11/71, OSNCP 1971, nr 10, poz. 166). Przyjęcie, że sędzia powinien realizować dodatkową pracę bez ograniczeń czasowych, także w niedziele i dni świąteczne, bez precyzyjnego określenia sytuacji, w których jest to dopuszczalne (np. w razie konieczności na zasadzie analogii z art. 151 k.p.), wydaje się niesłuszne i godzi w zasadę sprawiedliwości społecznej wyrażoną w art. 2 Konstytucji RP. Argumentacja, że owe szczególne obowiązki, niedogodności i ograniczenia są kompensowane szczególnymi uprawnieniami przysługującymi tej grupie zawodowej, nie wydaje się przekonująca. Owszem, sędziowie korzystają z dodatkowych rozwiązań, takich jak na przykład urlop dla poratowania zdrowia (art. 93 p.u.s.p.) czy też stan spoczynku (art. 180 ust. 3-4 Konstytucji i art. 69), pojawiają się jednak także pewne ograniczenia związane z tym statusem, chociażby brak możliwości podjęcia dodatkowego zatrudnienia (art. 86 p.u.s.p.). Nie wydaje, aby za taką stałą towarzyszącą sędziemu niedogodność uznać również wykonywanie pracy poza jakimikolwiek normami czasu pracy - dodatkowe uprawnienia nie mogą być traktowane jako rekompensata stałej pracy poza „normalnymi” godzinami pracy i na taką wykładnię nie powinno być przyzwolenia.

Brak wyraźnej regulacji w omawianym zakresie stanowi, moim zdaniem, podstawę do wyprowadzenia wniosku o posiłkowym stosowaniu w tym zakresie przepisów kodeksowych, zwłaszcza że Sąd Najwyższy w przytaczanych orzeczeniach wskazywał jednocześnie, że sędziom przysługuje prawo do odpoczynku (art. 132-133 k.p.), i w tym zakresie uczynił odesłanie - na zasadzie art. 5 k.p. - do stosowania odpowiednich przepisów kodeksowych, co wydaje się pewną niekonsekwencją. Należy bowiem jednoznacznie przesądzić przedmiot dopuszczalności bądź też niestosowania regulacji powszechnego prawa pracy - jak bowiem ustalić owe okresy odpoczynku, skoro czas pracy sędziego nie podlega wymiernemu ustaleniu i nie jest ujęty w sztywne ramy? Jak zatem weryfikować wypełnianie przez pracodawcę tego obowiązku? Podkreślenia wymaga, że wykonywanie przez sędziego pracy w czasie, który zgodnie z przepisami prawa powinien stanowić czas wolny pracownika i który należy pozostawić do jego dyspozycji, nie zasługuje na aprobatę także ze względów natury społecznej. Sędzia wykonuje doniosłe społecznie zadania: orzekając, wpływa na sytuację osób trzecich. Prawo do odpoczynku w przypadku sędziów nabiera również szczególnego znaczenia z uwagi na odpowiedzialność, jaka jest związana z pełnieniem urzędu i z zadaniami, których kontrola wykonania powinna uwzględniać zarówno parametry jakościowe, jak i ilościowe. Sędziowie są bowiem w pewnym sensie „rozliczani” ze swojej pracy w drodze kontroli instancyjnej.

Przyjmując, że sędziowie wykonują pracę w systemie zadaniowego czasu pracy, art. 83 ustawy należy w istocie uznać za powtórzenie art. 140 k.p. (Ostaszewski 2009, s. 214 i n.), tyle że ujęty bardziej syntetycznie. Model czasu pracy, w którym pracują sędziowie, niezależnie od jego nazwy, ma służyć zabezpieczeniu niezależności władzy 
sądowniczej, jej zdolności do niezawisłego wymierzania sprawiedliwości i realizacji konstytucyjnego prawa do sądu. $Z$ pewnością takie założenie nie daje jednak podstaw do obciążania sędziów pracą bez żadnych ograniczeń. Sędzia nie przestaje bowiem być pracownikiem, a jego czas pracy powinien podlegać oznaczeniu, choćby względnemu, i być wymierny. Wykonywanie pracy przez przemęczonych i nadmiernie obciążonych pracą sędziów pozostaje w kolizji z takim założeniem. Niejednokrotnie zdarza się i nie jest to sytuacja przejściowa (usprawiedliwiona okolicznościami), że permanentny nadmiar spraw - zadan - w sposób oczywisty narusza wszelkie normy czasowe i nawet bez bliższej analizy można wyprowadzić wniosek, że nie są one możliwe do wykonania w rozsądnym czasie. Owszem, dają się one wykonać w dłuższej perspektywie czasu, przy nieprzekraczaniu norm czasu pracy, stojąc jednak w sprzeczności z konstytucyjnym prawem obywatela do rozpoznania jego sprawy nie tylko przez niezależny, bezstronny i niezawisły sąd, ale również sprawnie i bez przewlekłości (art. 45 Konstytucji RP). Nadmiar pracy sędziów utrzymujący się na stałym wysokim poziomie nie pozwala na realizację tego założenia. Ustalenie, czy liczba tych zadań jest wygórowana (zawyżanie norm ilościowych) i czy pracownik sędzia był w stanie je wykonać, należy w ewentualnym postępowaniu do niego, niemniej jednak choć dowodzenie w tym zakresie byłoby trudne, nie jest jednak niemożliwe.

Na koniec nasuwa się również pewna refleksja natury ogólnej. Aktualna sytuacja z pewnością skłania do przemyśleń nad organizacją wymiaru sprawiedliwości oraz zapewnieniem sędziom odpowiednich warunków pracy. W wyniku ciągle wzrastających obowiązków nakładanych na sądy i sędziów przez ustawodawcę oraz niekiedy w związku z brakiem adekwatnej infrastruktury, odpowiedniego zaplecza technicznego czy sprawnych i efektywnych instrumentów proceduralnych sędziowie zobowiązani są do świadczenia pracy w wymiarze znacznie odbiegającym od cywilizowanych standardów. Dowolne obciążanie pracą nie tylko prowadzi do naruszenia praw o charakterze socjalno-kulturowym, ale także narusza prawo do życia w rodzinie, do dostatecznego odpoczynku, do prywatności, do rozwoju zainteresowań czy do korzystania ze zdobyczy kultury. Oczywiste jest, że sprawując wymiar sprawiedliwości, sędziowie pełnią rolę służebną wobec społeczeństwa, co wymaga poświęceń, oraz że ich czas pracy musi być odpowiednio elastyczny, co pozwala na skuteczne, rzetelne i terminowe realizowanie konkretnych zadań publicznych, jednakże nie oznacza to, że czas ten ma być niczym nieograniczony. Żadne zasady, wartości czy normy konstytucyjne nie dają podstaw do odstąpienia od zasady traktowania sędziów w kwestii ochrony czasu pracy na równi z innymi pracownikami, z powołaniem się na jakiś bliżej nieokreślony etos społeczny towarzyszący tej grupie. 


\section{Bibliografia}

Bury B. (2007) Praca w godzinach nadliczbowych jako obowiazek pracownika, Warszawa.

Bury B. (2009) Zadaniowy czas pracy sędziów a prawo do wynagrodzenia za prace ponadwymiarowa, „Monitor Prawa Pracy”, nr 11.

Bury B. (2013) Model czasu pracy sędziów, „Monitor Prawa Pracy”, nr 7.

Driczinski S. (2001) Stosowanie definicji czasu pracy $w$ czasie pracy określonym wymiarem zadań - artykuł dyskusyjny, „Praca i Zabezpieczenie Społeczne”, nr 2.

Gonera K. (2013) [w:] A. Górski (red.), Prawo o ustroju sq̨dów powszechnych. Komentarz, LEX.

Haÿduk-Hawrylak I., Kołecki B., Wleklińska A. (2018) Prawo o ustroju sq̨dów powszechnych. Komentarz, Warszawa.

Iwulski J. (2002) [w:] T. Ereciński, J. Gudowski, J. Iwulski, Komentarz do prawa o ustroju sądów powszechnych i ustawy o Krajowej Radzie Sadownictwa, Warszawa.

Kurzynoga M. (2011) Czas pracy sędziego sądu powszechnego [w:] L. Florek (red.), Czas pracy, Warszawa.

Liszcz T. (1989) Rekodyfikacja prawa pracy a pragmatyki pracownicze, „Praca i Zabezpieczenie Społeczne", nr 6.

Małysz F. (1979) Stosowanie i wynagradzanie pracy w godzinach nadliczbowych, „Praca i Zabezpieczenie Społeczne", nr 3.

Muszalski W. (2001) Zadaniowy czas pracy i aktualne problemy regulacji czasu pracy, „Praca i Zabezpieczenie Społeczne”, nr 5.

Nycz T. (2004) Czas pracy od 1 stycznia 2004 roku, Kraków-Tarnobrzeg.

Ostaszewski W. (2009) Glosa do uchwały SN z dnia 8 kwietnia 2009 r., II PZP 2/09, „Przegląd

Sądowy", nr 11-12.

Piotrowski W. (1987) Ocena stanu pragmatyk i propozycje ich uporządkowania [w:] M. Matey,

Z. Salwa (red.), Przesłanki i kierunki reformy prawa pracy i ubezpieczeń społecznych, Wrocław $\mathrm{i}$ in.

Rączka K. (2004) Systemy czasu pracy w znowelizowanym Kodeksie pracy, „Praca i Zabezpieczenie Społeczne", nr 2.

Rycak A. (2009) Czy sędziowie pracują w zadaniowym czasie pracy?, „Monitor Prawa Pracy”, nr 4. Seler R. (1974) Pragmatyki pracownicze a kodeks pracy, „Praca i Zabezpieczenie Społeczne”, nr 12. Sobczyk A. (2005) Zasady prawnej regulacji czasu pracy, Warszawa.

Stanibuła B. (2005) Ewolucja zasad stosowania zadaniowego czasu pracy, „Praca i Zabezpieczenie Społeczne", nr 8.

\section{Orzecznictwo}

Postanowienie ETS z 11 stycznia 2007 r., C-437/05, Vorel.

Wyrok ETS z 8 lutego 2001 r., C-350/99, Wolfgang Lange p. Georg Schüneman sp. z o.o.

Wyrok ETS z 1 grudnia 2005 r., C-14/04, Dellas.

Postanowienie SN z 7 grudnia 1999 r., I PKN 427/99, OSNAPiUS 2001, nr 8, poz. 274. 
Postanowienie SN z 27 sierpnia 2015 r., SNO 47/15, LEX nr 1809890.

Uchwała SN z 4 czerwca 1971 r., III PZP 11/71, OSNCP 1971, nr 10, poz. 166.

Uchwała SN z 8 kwietnia 2009 r., II PZP 2/09, BSN 2009, nr 4, poz. 27.

Wyrok SN z 12 stycznia 1999 r., I PKN 526/98, OSNAPiUS 2000, nr 4, poz. 147.

Wyrok SN z 12 listopada 2003 r., SNO 71/03, LEX nr 470253.

Wyrok SN z 19 listopada 2003 r., I PK 476/02, OSNP 2004, nr 22, poz. 382.

Wyrok SN z 4 listopada 2004 r., SNO 44/04, niepubl.

Wyrok SN z 26 czerwca 2014 r., SNO 3/14, LEX nr 1504850.

Wyrok SN z 22 czerwca 2015 r., SNO 36/15, LEX nr 1755918.

Wyrok SN z 15 września 2015 r., III KRS 49/15, LEX nr 2288956.

Wyrok SN z 17 maja 2016 r., SNO 10/16, LEX nr 2053645.

Wyrok TK z 24 lutego 2004 r., K 54/02, OTK-A 2004, nr 2, poz. 10.

Wyrok TK z 7 maja 2013 r., SK 11/11, OTK-A 2013, nr 4, poz. 40. 